\title{
Volatility Analysis and Volatility Spillover Analysis of Indonesia's Coffee Price Using Arch/Garch, and Egarch Model
}

\author{
Meinar Fithria Rahayu (Corresponding author) \\ Dept. of Agriculture Economics, Brawijaya University \\ Jl. Raya No. 46 Purwosari-Pasuruan, 67162, East Java, Indonesia \\ Tel: 628-223-213-4339Ｅ-mail: mey.faith@gmail.com

\section{Wen-I Chang} \\ Lecturer, Department of Agribusiness Management \\ National Pingtung University of Science and Technology, Taiwan
}

Ratya Anindita

Lecturer, Department of Agriculture Economics, Brawijaya University, Indonesia

Received: March 5, 2015 Accepted: March 25, 2015

doi:10.5296/jas.v3i2.7185 URL: http://dx.doi.org/10.5296/jas.v3i2.7185

\begin{abstract}
This study aims to analyze the best model to expect volatility of Indonesia's coffee price using ARCH/GARCH model and to measure the coffee price volatility spillover of International market for Indonesia's coffee price using EGARCH model. These models use different conditional variance specifications to catch up the asymmetry. The empirical results show that GARCH (1.1) model seems to better describe the Indonesia's coffee price volatility. From the EGARCH analysis known that International coffee price has an asymmetric effect on Indonesia's return coffee price and indicate that domestic coffee market is not efficient.
\end{abstract}

Keywords: Indonesian, Coffee, Price, Volatility, Spillover, ARCH/GARCH, EGARCH 


\section{Introduction}

The role of plantation commodities for Indonesia's economy is very large, when the global economic crisis in 1998 and 2008, the manufacturing sector in Indonesia converting the vulnerability, but the plantation sector emerged as the savior of the Indonesia's economy through its contribution to domestic income, foreign exchange gains, employment, as well as the economic development of the region.

Coffee is one of the leading commodity in the Indonesia's agricultural sector, Indonesia's coffee production has reached 600 thousand tons per year and more than 80 percent comes from public forest. In addition, Indonesia's coffee is one of the commodities that have quite important contribute as the third largest foreign exchange earner after wood and rubber. Foreign exchange earned from coffee exports could reach Rp 7,784 billion (2009), involving 1.97 million households that supports 5 million peasant family life. Coffee as a plantation crop is one commodity that is attractive to many countries, especially developing countries because coffee plantations provide employment opportunities are quite high and can generate much needed foreign exchange for national development (Spillane, 1990).

Approximately $63 \%$ of Indonesia's coffee are for export, it makes the stability of Indonesia's coffee economy is highly depend on world market conditions. In other words, the price of coffee in Indonesia depends on coffee production from other exporting countries, such as Brazil, Colombia and Vietnam. World coffee crisis in 2000 that occurred because of the success of Vietnam's coffee production and the increasing success of Brazil to minimize disruption caused frost coffee's role in the Indonesia's economy is fading. Coffee prices fell because of flooding the world's coffee production and continued to fall until it reaches its lowest price in 30 years in early 2002 (FAO, 2002). These conditions have a direct impact on the movement of the Indonesia's producers, coffee price, because the price of coffee in Indonesia is very depend on the international market. The unstable movement of coffee prices in the international market will affect the domestic coffee prices, Indonesia's foreign exchange earnings and also will affect both coffee farmers and exporters decision. When the international coffee prices are higher than domestic prices, exporters prefer to sell their coffee to the international market. So that, these decisions will ultimately affect the coffee price in the domestic market.

The coffee price movements are irregular showed varying price changes or volatility, called a swing irregularity of the data. This volatility also describes the coffee price transmission (spillover) which reflects the price transmission from the international market to the farmer's domestic market level or vice versa and creating instability in global commodity markets (Stigler, 2011).

The Auto regressive Conditional Heteroscedasticity (ARCH), Generalized Auto regressive conditional heteroscedasticity $(\mathrm{GARCH})$ family is widely used in the measurement of price volatility in agricultural commodities (Yang et al, 2003; Hernandez et al, 2009; Fakari et al, 2013) because ARCH/GARCH family are suitable for use in studies using time series data. This model allows the heterocedasticity of data that are usually happening the time series commodity price, this model also can investigate time different attributes expected price and price volatility. Exponential Generalized Autoregressive conditional heteroscedasticity 
(EGARCH) model, check volatility spillover and provided evidence of volatility spillovers in agricultural markets (Buguk et al, 2013). EGARCH models are one form of development of ARCH/GARCH models that can identify the presence of symmetric effects among the variables used in the study, so that the EGARCH models can be used to determine the level of volatility spillover between the International coffee prices and the price of coffee in Indonesia.

Based on the study above, this research is greatly important with the aim to:

1. Estimate the best model of Indonesia's coffee price volatility using ARCH/GARCH Model.

2. Measuring the coffee price volatility spillover of the international market for Indonesia's coffee price using EGARCH Model.

\section{Literature Review}

Historical volatility, also called realized volatility, is based on the observed movements of prices over the long term, and indicates how volatile an asset or commodity price has been in the past (Bernardina, 2012). It showed the volatility level observed in the past on the basis of fluctuations in the price of the commodity. Historical volatility is determined by using a statistical tool known as standard deviation. Implied volatility derives from market forecasts of future variations in the commodity price. Evaluation of the premium for an option is based on market fundamentals, the option exercise price, numbers of days until expiration and volatility. The only unknown component is volatility, or so-called implied volatility. A number of mathematical and econometric methods have been developed to estimate this volatility component on the basis of the Black-Scholes model. Measurements of historical and future volatilities have an impact on evaluations and profits of a number of financial products. Volatility measurements are regarded as a barometer of investor sentiment. A high volatility level generally indicates an extremely nervous market while a low volatility level indicates a low-risk market and a consequent tendency for risk-taking. (International Coffee Council, 2009).

Volatility modeling is popular in financial economics. Financial variables such as stock price, interest rate and exchange rates are being modeled frequently by using financial econometric models, especially ARCH classes of models (Engel, 2001; Gee, 2010; Grobys 2010; Diebold et al, 2012; Ezzaty, 2013). However, volatility and volatility spillover analysis can also be performed to see the volatility of food price (Kuwornu, 2011; Kane, 2013) a wide variety of agricultural commodities (Jordaan, 2007; Benavides, 2009; Shiferaw, 2012; Sembiring, 2013), plantations (Malan, 2013), livestock (Buguk, 2013) even for the oil price (Salisu, 2012; Dhaoui, 2014).

\section{Methods}

\subsection{Data Description}

The data that used in this research is annual data from 1980-2011. This data collected from many resources, such as Indonesia's Bureau of Statistic online database, Indonesia's Ministry 
of Agriculture online database and Food and Agriculture (FAO) online database. Variables in this research are producer Coffee price from 1980-2011.

\subsection{Unit Root Test}

A series is stationary (weakly or covariance) if the mean and autocovariances of the series do not depend on time. Any series that is not stationary is said to be nonstationary. A common example of a nonstationary series is the random walk:

$$
y_{t}=y_{t-1}+\varepsilon_{t} y_{t}=y_{t-1}+\varepsilon_{t}
$$

where $\varepsilon$ is a stationary random disturbance term. The series has a constant forecast value, conditional on, and the variance is increasing over time.

\subsection{ARCH-LM-Test}

The ARCH-LM test is a Lagrange multiplier (LM) test for autoregressive conditional heteroscedasticity $(\mathrm{ARCH})$ in the residuals (Engle, 1982). This particular specification of heteroscedasticity was motivated by the observation that in many financial time series, the magnitude of residuals appeared to be related to the magnitude of recent residuals. ARCH in itself does not invalidate standard LS inference. However, ignoring ARCH effects may result in loss of efficiency.

The ARCH-LM test statistic is computed from an auxiliary test regression. To test the null hypothesis that there is no ARCH up to order q in the residuals, we run the regression:

$$
e_{t}^{2}=\beta_{0}+\left(\sum_{s=1}^{q} \beta_{s} e_{t-s}^{2}\right)+v_{t}
$$

Where e is residuals. This is a regression of the squared residuals on a constant on lagged squared residuals up to order q.

\subsection{ARCH Model}

Autoregressive Conditionally Heteroskedasticity (ARCH) model is a particular nonlinear model. In particular ARCH models assume the variance of the current error term or innovation to be a function of the actual sizes of the previous time periods' error terms: often the variance is related to the squares of the previous innovations (Brook, 2008).

The model of $\mathrm{ARCH}$ is written as:

$$
\sigma_{t}^{2}=\alpha_{0}+\alpha_{1} u_{t-1}^{2}
$$

\subsection{GARCH Model}

The GARCH Model was developed independently by Bollerslev and Taylor (1986). The GARCH model allows the conditional variance to be dependent upon previous own legs, so 


\section{Macrothink}

that the conditional variance equation of $\mathrm{GARCH}$ is:

$$
\sigma_{t}^{2}=\alpha_{0}+\alpha_{1} u_{t-1}^{2}+\beta \sigma_{t-1}^{2} \sigma_{t}^{2}=\alpha_{0}+\alpha_{1} u_{t-1}^{2}+\beta \sigma_{t-1}^{2}
$$

\subsection{EGARCH Model}

The exponential GARCH model was proposed by Nelson (1991).

$$
\ln \sigma_{t}^{2}=\alpha_{0}+\alpha_{1 a} \frac{\varepsilon_{t-1}}{\sigma_{t-1}}+\alpha_{1 b}\left(\frac{\varepsilon_{t-1}}{\sigma_{t-1}}-E\left[\frac{\varepsilon_{t-1}}{\sigma_{t-1}}\right]\right)+\beta_{1} \ln \sigma_{t}^{2}
$$

For $\varepsilon_{t} \sim N\left(0, \sigma_{t}^{2}\right) \varepsilon_{t} \sim N\left(0, \sigma_{t}^{2}\right)$ the standardized variable ${ }^{\frac{\varepsilon_{t} \varepsilon_{t}}{\sigma_{t} \sigma_{t}}}$ follows a standard normal

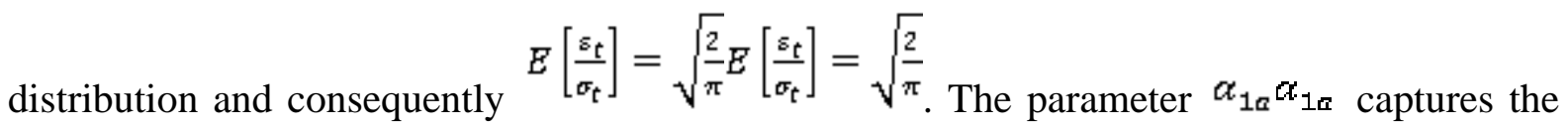

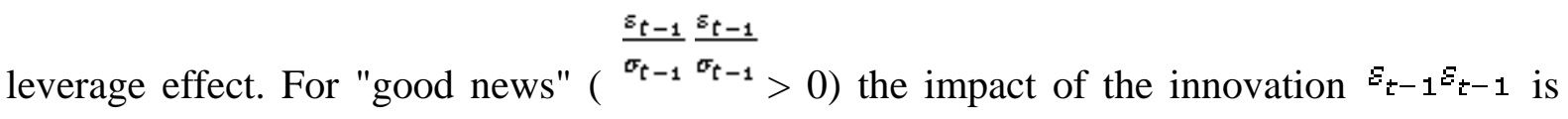

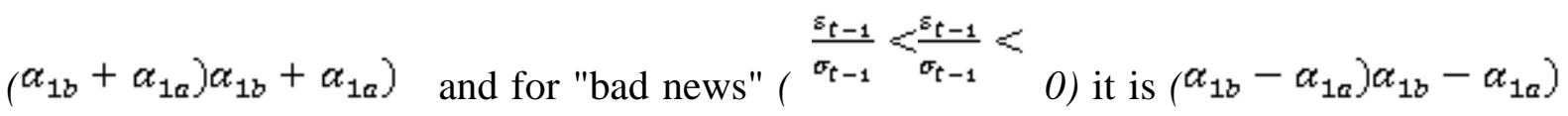
If $\alpha_{1 a} \alpha_{1 a}=0$, In $\sigma_{t}^{2} \sigma_{t}^{2}$ responds symmetrically to $\frac{\varepsilon_{t-1} \varepsilon_{t-1}}{\sigma_{t-1} \sigma_{t-1}}$. To produce a leverage effect, $\alpha_{1 a} \alpha_{1 a}$ must be negative. The fact that the EGARCH process is specified in terms of log-volatility implies that $\sigma_{t}^{2} \sigma_{t}^{2}$ is always positive and, consequently, there are no restrictions on the sign of the model parameters.

\section{Result and Discussion}

\subsection{Data Analysis}

Data used in this study are rate of producer coffee price from 1980 through 2011, the time series data collected from various sources such as the Food and Agriculture (FAO) online database, Indonesia's Ministry of Agriculture online database, Association of Indonesia's Coffee Exporters and Producers (AICE) online database and some related papers. The data are analyzed the volatility of the coffee price in Indonesia, Brazil, Colombia and Vietnam is the return value of the producer coffee price, this is done because the volatility is the variance of the return value. Indonesia's coffee price data is used to analyze the Indonesia's coffee price, and Brazilia's, Colombia's and Vietnam's coffee price data as International coffee market, are used to measure the volatility spillover of International coffee price to Indonesia's coffee price. 


\section{$\triangle 1$ Macrothink}

Table 1. Descriptive statistic, return value of Indonesia's, Brazilian, Colombian and Vietnamese Coffee Price

\begin{tabular}{|l|l|l|l|l|}
\hline & $\begin{array}{l}\text { Indonesia } \\
\text { (percent) }\end{array}$ & $\begin{array}{l}\text { Brazil } \\
\text { (percent) }\end{array}$ & $\begin{array}{l}\text { Colombia } \\
\text { (percent) }\end{array}$ & $\begin{array}{l}\text { Vietnam } \\
\text { (percent) }\end{array}$ \\
\hline Mean & 0.038701 & 0.042325 & 0.043266 & 0.045930 \\
\hline Median & 0.046782 & 0.077283 & 0.051636 & 0.029725 \\
\hline Maximum & 1.028347 & 1.057496 & 0.959134 & 1.142783 \\
\hline Minimum & -1.079214 & -1.141771 & -1.230161 & -1.015751 \\
\hline Std. Dev. & 0.321664 & 0.336271 & 0.331190 & 0.328117 \\
\hline
\end{tabular}

The descriptive statistic of data is included mean, median, maximum, minimum, standard deviation, is shown in Table 1. Mean is the average value of 31 observed data in this research, the mean value of Indonesia's return coffee price is 3.8 percent, Brazil is 4.2 percent, Colombia is 4.3 percent and Vietnam is 4.6 percent. The mean value of each country is less than their median value, except Vietnamese return coffee price. It is mean that the distribution of observed data is concentrated at low, value, but for the Vietnamese return coffee price the observed data is concentrated at high value. This is because the difference between the mean value and the median value is big.

\subsection{Unit Root Test}

The unit root test is used to test the notion that a time series data are not stationary, the data is said to be stationary that data is flat, does not contain a trend component, with constant diversity, and there are no periodic fluctuations. Commonly used to test the data stationarity is the augmented Dickey-Fuller (ADF) test, this test is indicate the presence of a unit root null hypothesis.

The augmented Dickey-Fuller tests are shown a variable follow a unit-root process. The null hypothesis is that the variable contains a unit root, and the alternative is that the variable was generated by a stationary process. The result of unit root test from real return coffee price, first difference form of return coffee and second difference of return coffee price is shown in Table 5.2. The return coffee price value for Indonesia, Brazil, Colombia and Vietnam are already significant at level, so all results of each form (level, first difference, second difference) return coffee price are significant, or less than is a critical value of $1 \%, 5 \%$ and $10 \%$. Meaning that all forms of return coffee price data are stationer, so the data used to predict the volatility of Indonesia's, Brazilian, Colombian and Vietnamese coffee price is the real return value of coffee price or the return coffee price of each country at level.

Table 2. Unit-root test of Indonesia's, Brazilian, Colombian, and Vietnamese return coffee price

\begin{tabular}{|l|l|l|l|}
\hline Series & Level & First Difference & Second Difference \\
\hline Indonesia & $-7.68 * * *$ & $-7.88 * * *$ & $-10.19 * * *$ \\
\hline Brazil & $-7.33 * * *$ & $-7.69 * * *$ & $-9.89 * * *$ \\
\hline Colombia & $-8.16 * * *$ & $-8.68 * * *$ & $-12.07 * * *$ \\
\hline
\end{tabular}




\begin{tabular}{|c|c|c|c|c|}
\hline Vietnam & \multicolumn{2}{|l|}{$-7.19 * * *$} & $-7.46 * * *$ & $-10.68 * * *$ \\
\hline \multirow{3}{*}{\multicolumn{2}{|c|}{ Test critical values for Indonesia }} & $1 \%$ level & & -3.670170 \\
\hline & & $5 \%$ level & & -2.963972 \\
\hline & & $10 \%$ level & & -2.621007 \\
\hline \multirow{3}{*}{\multicolumn{2}{|c|}{ Test critical values for Brazil }} & $1 \%$ level & & -3.699871 \\
\hline & & $5 \%$ level & & -2.976263 \\
\hline & & $10 \%$ level & & -2.627420 \\
\hline \multirow{3}{*}{\multicolumn{2}{|c|}{ Test critical values for Colombia }} & $1 \%$ level & & -3.670170 \\
\hline & & $5 \%$ level & & -2.963972 \\
\hline & & $10 \%$ level & & -2.621007 \\
\hline \multirow{3}{*}{\multicolumn{2}{|c|}{ Test critical values for Vietnam }} & $1 \%$ level & & -3.670170 \\
\hline & & $5 \%$ level & & -2.963972 \\
\hline & & $10 \%$ level & & -2.621007 \\
\hline
\end{tabular}

Note: statistical significance at $1 \%(* * *), 5 \%(* *)$, and $10 \%(*)$

\subsection{Heteroscedasticity Test (ARCH effect)}

Heteroscedasticity test is used to prove that the data are heteroscedastic and has an ARCH effect. The result of heteroscedasticity tests is shown in table 3 below.

Table 3. Heteroscedasticity Test: ARCH

\begin{tabular}{|l|l|l|l|l|}
\hline & Indonesia & Brazil & Colombia & Vietnam \\
\hline F-statistic & $5.864229 * * 6.652265 * * 3.599933 * 7.044679 * *$ \\
\hline Obs $*$ R-squared $5.195065 * * 5.759160 * * 3.417665 * 6.030598 * *$ \\
\hline
\end{tabular}

Note: statistical significance at $1 \%(* * *), 5 \%(* *)$, and $10 \%(*)$

The result of heteroscedasticity tests of return coffee price for Indonesia, Brazil, Colombia and Vietnam shows that the heteroscedasticity or ARCH effect are significant at $5 \%$ for Indonesia's, Brazilian, Vietnamese return coffee price and significant at $10 \%$ for Colombian return coffee price. Meaning that the appropriate model for measuring return coffee price volatility of Indonesia's, Brazilian, Colombian and Vietnamese are ARCH/ GARCH family.

\subsection{Indonesia’s Coffee Price Volatility}

$\mathrm{ARCH}$ and GARCH models are used to expect the return of Indonesia's coffee price and the volatility of Indonesia's return coffee price equation. As the result, the expected for Indonesia's return coffee price can be present as follows:

$$
C P_{t}^{\theta}=d_{0}+d_{1} C P_{t-1}+d_{2} C P_{t-2}+\varepsilon_{2 t}
$$

Where:

$C P_{t}^{\theta} C P_{t}^{\theta} \quad$ : expected return coffee price 
$C P_{t-1} C P_{t-1}:$ return of producer coffee price in time $\mathrm{t}-1$

$C P_{t-2} C P_{t-2} \quad:$ return of producer coffee price in time $\mathrm{t}-2$

The expected variance of return coffee price gets from the variance equation as follow:

$$
\sigma_{t}^{2}=a_{0}+\alpha \varepsilon_{2 t-1}^{2}+\beta h_{t-1}
$$

The variance equation is called GARCH conditional variance equation, this equation is also known as the volatility of Indonesia's return coffee price equation. According to the equation, $\sigma_{t}^{2} \sigma_{t}^{2}$ is specified as a linear function of $p$ lagged-square residuals and its own $q$ lagged conditional variance. The result of GARCH-typed estimation of Indonesia's return coffee price to the expected price equation are presented in table 4.

The table 4 shows the analytical result of $\mathrm{ARCH}$ and GARCH model of the price equation. The Akaike info criterion and Schwarz information criterion is used to rank the three models of Indonesia's return coffee price, because it allows a degree of freedom comparison of the models' performance. A comparison of AIC and SIC values shows that GARCH $(1,1)$ model is the most appropriate to describe the expected price equation system.

Table 4. Result of Indonesia's return coffee price volatility

\begin{tabular}{|c|c|c|c|}
\hline & $\mathrm{ARCH}(1)$ & $\operatorname{GARCH}(1,1)$ & GARCH $(0,1)$ \\
\hline \multicolumn{4}{|l|}{ Mean Price Equation } \\
\hline$a_{0}$ & $0.197 * * *$ & $0.079 * * *$ & 0.089 \\
\hline$C P_{t-1}$ & -0.587 & 0.017 & $-0.381^{*}$ \\
\hline$C P_{t-2}$ & $-0.277 * *$ & $0.055 * * *$ & -0.212 \\
\hline \multicolumn{4}{|l|}{ Variance Equation } \\
\hline$a_{0}$ & 0.010 & 0.001 & 0.003 \\
\hline$\alpha$ & $1.669^{* *}$ & $-0.200 * * *$ & \\
\hline$\beta$ & & $1.239 * * *$ & $1.038 * * *$ \\
\hline$\alpha+\beta$ & 1.669 & 1.039 & 1.038 \\
\hline Akaike info criterion & 0.434 & -0.089 & 0.533 \\
\hline Schwarz criterion & 0.669 & 0.193 & 0.769 \\
\hline
\end{tabular}

Note: statistical significance at $1 \%(* * *), 5 \%(* *)$, and $10 \%(*)$

$\alpha+\beta<1$ (low volatility), $\alpha+\beta=1$ (high volatility), $\alpha+\beta>$ (extreme volatility)

The equation for expected of Indonesia's return coffee price is:

$$
C P_{t}^{\theta}=0.079+0.017 C P_{t-1}+0.055 C P_{t-2}+\varepsilon_{2 t}
$$




\section{MlMacrothink}

The equation means that the increasing of $1 \%$ of Indonesia's producer returns coffee price at time t-1 will increase $1.7 \%$ of the expected Indonesia's return producer coffee price and increasing $1 \%$ of Indonesia's producer return coffee price at time t-2 will increase $5.5 \%$ of the expected Indonesia's return producer coffee price. With GARCH $(1,1)$, also obtained an equation for the return volatility of Indonesia's coffee price. The equation shows as follows:

$$
h_{t}=0.001-0.200 \varepsilon_{2 t-1}^{2}+1.239 h_{t-1} h_{t}=0.001-0.200 \varepsilon_{2 t-1}^{2}+1.239 h_{t-1}
$$

From the equation above, shows that the total value of $\alpha+\beta$ is equal to 1 . This result indicates that the return price volatility of Indonesia's producers coffee is high.

\subsection{Indonesia's Coffee Price Volatility Spillover}

Table 5 presents the empirical results of the estimated EGARCH between Indonesia's return coffee prices and the return coffee price of the world's largest coffee exporter countries, Brazil, Colombia and Vietnam. The results of the average equation of Indonesia return coffee price are positively affected by the return of Brazilian coffee prices at $1 \%$ significance level, which is implies that as the world's largest coffee producer, Brazil plays an important role on the world coffee price volatility. This is evidenced when the world coffee crisis in 2000 which occur due to Brazil's success in minimizing disruption frost that causing coffee prices fell because of flooding the world's coffee production, world coffee prices continue to fall until it reaches its lowest point in 30 years in early 2002 (FAO, 2002).

Like Brazil, Vietnam's returns coffee prices also have a positive effect on returns and significant at the level of $1 \%$ for Indonesia's return coffee prices. This happens because Vietnam is an Indonesia's major competitor as a coffee exporter, both countries produce the same type, IE robusta coffee. While the Colombian coffee prices return a negative effect, but no significant effect on the Indonesia's return coffee price.

Table 5. Volatilities Spillover of Brazilian, Colombian and Vietnamese Coffee Price to Indonesia's Return Coffee Price.

\begin{tabular}{|l|l|}
\hline \multicolumn{1}{|l|}{ Variable } & Coefficient \\
\hline Price Spillover \\
\hline C & $-0.016515^{* *}$ \\
\hline Brazil & $0.470787^{* * *}$ \\
\hline Colombia & -0.013669 \\
\hline Vietnam & $0.505254^{* * *}$ \\
\hline \multicolumn{2}{|l}{ Volatility Spillover } \\
\hline$\omega$ & $-4.592419^{*}$ \\
\hline$\alpha$ & $-1.827363^{*}$ \\
\hline$\gamma$ & -0.348790 \\
\hline$\beta$ & -0.002515 \\
\hline BRAZIL & -3.533541 \\
\hline COLOMBIA & -1.126942 \\
\hline VIETNAM & 3.730985 \\
\hline
\end{tabular}

Note: statistical significance at $1 \%(* * *), 5 \%(* *)$, and $10 \%(*)$ 
$\alpha$ ' stands for the symmetric effect of the model, from table 5 it is known that $\alpha$ value of Indonesia's return coffee price is significant at $1 \%$. This indicates that Indonesia's returns coffee price is asymmetric, and indicate that the return coffee price volatility of Brazil, Colombia and Vietnam are not significant or has no significant effect of Indonesia's return coffee price volatility.

\section{Conclusion}

This study has investigated the return price volatility of Indonesia's coffee price and volatility spillover of Brazilian, Colombian and Vietnamese return coffee price to Indonesia's Coffee price, the expected equation was examined with ARCH, GARCH and EGARCH model. The empirical results of the expected price show that, GARCH $(1,1)$ model conforms as the most appropriate model to describe the expected return price of Indonesia's coffee. From the variance equation GARCH $(1,1)$ or Indonesia's coffee price volatility, shows that the Indonesia's return coffee price volatility is high. This is because the Indonesia's coffee is exported product which is depend on the international coffee market. But from the average return price spillover analysis, it is known that Brazil and Vietnam have a positive and significant effect to the average equation of Indonesia's Return Coffee Price. For volatility spillover analysis, known that Indonesia's returns coffee price is asymmetric, and the return coffee price volatility of Brazil, Colombia and Vietnam has no significant effect of Indonesia's return coffee price volatility. Indonesian domestic coffee prices are controlled by middlemen traders, this leads to an asymmetric effect between international coffee prices to Indonesian coffee price. The game price by middlemen is causing the coffee price at farm level is low, and lower the welfare of Indonesian coffee farmers.

Government should provide a policaes to improve and stabilize the Indonesia's domestic coffee price to suppress the role of middleman in domestic coffee price play, so the welfare level of Indonesia coffee farmers can be assured, because based on the results of analysis show that the level Indonesia's coffee price volatility is significantly influenced by the coffee price of the previous year, this suggests that the Indonesia's coffee price is more influenced by the Indonesia's domestic market conditions than the international coffee market condition.

\section{Acknowledgement}

Thanks for Prof. Ir. Ratya Anindita, MS., Ph.D, Brawijaya University, Indonesia and Wen-I Chang, Ph.D, National Pingtung University of Science and Technology, Taiwan.

\section{References}

Bernardina, Algieri. (2012). Price Volatility, Speculation and Excessive Speculation in Commodity Markets: sheep or shepherd behaviour?. ZEF- Discussion Papers on Development Policy No. 166, Center for Development Research, Bonn, May 2012, pp. 37.

FAO. (2002). Commodity Market Review 2001-02. Commodities And Trade Division Food And Agriculture Organization Of The United Nations. Food and Agriculture Organization of The United Nations. Rome. Avaiable at ftp://ftp.fao.org/docrep/fao/004/y3007e/y3007e00.pdf

Stigler, Matthieu. (2011). Safeguarding Food Security in Volatile Global Markets, ch. 2. Food 
and Agriculture Organization of The United Nations. Rome. Available at http://www.fao.org/docrep/013/i2107e/i2107e27.pdf

Gee, Chan Sok et al. (2010). Volatility Spillovers of the Major Stock Markets in ASEAN-5 with the U.S. and Japanese Stock Markets. International Research Journal of Finance and Economics. Available at: http://repository.um.edu.my/6874/1/irjfe_44_12.pdf

Grobys, Klaus. (2010). Have Volatility Spillover Effects Of Cointegrated European Stock Markets Increased Over Time?. The Review of Finance and Banking Volume 02, Issue 2, Year 2010. Available at: http://www.rfb.ase.ro/articole/paper3.pdf

Ezzati, Parinaz. (2013). Analysis Of Volatility Spillover Effects: Two-Stage Procedure Based On A Modified GARCH-M. The University of Western Australia. Available at: http://www.business.uwa.edu.au/_data/assets/pdf_file/0006/2385780/13-29-Analysis-of-Vol atility-Spillover-Effects-Two-Stage-Procedure-Based-on-a-Modified-GARCH-M.pdf

Diebold et al, (2012). Measuring Financial Asset Return and Volatility Spillovers, With Application to Global Equity Markets. University of Pennsylvania

Engle, Robert. (2001). GARCH 101: The Use of ARCH/GARCH Models in Applied Econometrics. Journal of Economic Perspectives_Volume 15, Number 4-Fall 2001-Pages 157-168. Available at: http://dx.doi.org/10.1257/jep.15.4.157

Jordaan et al. (2007). Measuring the Price Volatility of Certain Field Crops in South Africa using the ARCH/GARCH Approach. Agrekon, Vol 46, No 3 (September 2007). Available at: http://dx.doi.org/10.1080/03031853.2007.9523774

Kane, Gilles Quentin. (2013). Food Price Volatility In Cameroon: Causes, Transmission And Consequences. African Economic Research Consortium (AERC). Available at: http://aercafricaevents.org/papers/GroupE/CPPE1-KANE.pdf

Kuwornu et al. (2011). Analysis of Food Stuff Price Volatility in Ghana: Implications for Food Security. European Journal of Business and Management. Vol 3, No.4, 2011. Available at: http://www.iiste.org/Journals/index.php/EJBM/article/view/299/186

Benavides Guillermo. (2009). Price Volatility Forecasts For Agricultural Commodities: An Application of Volatility Models, Option Implieds and Composite Approaches for Futures Prices of Corn and Wheat. Journal of Management, Finance and Economics, vol. 3, n'um. 2 (2009), pp. 40-59. Available at: http://dx.doi.org/10.2139/ssrn.611062

Buguk, Cumhur. Darren Hudson, and Terry Hanson. (2013). Price Volatility Spillover in Agricultural Markets: An Examination of U.S. Catfish Markets. Journal of Agricultural and Resource Economics 28(1), 86-99. Copyright 2003 Western Agricultural Economics Association. Available at: http://ageconsearch.umn.edu/bitstream/30716/1/28010086.pdf

Sembiring, Elsa. 2013. Analysis of Price Volatility Spillover of Soyabean (Glycine max (L.) Merrill) in East Java. Greener Journal of Agricultural Sciences. 3(9), 656-662, September 2013. Available at: http://www.gjournals.org/GJAS/GJAS\%20Pdf/2013/September/071513732\%20Sembiring.pd 
$\mathrm{f}$ 2015, Vol. 3, No. 2

Shiferaw, Yegnanew Alemu. (2012). Modeling Volatility of Price of Some Selected Agricultural Products in Ethiopia: ARIMA/GARCH Applications. Hawassa University, Ethiopia. http://dx.doi.org/10.2139/ssrn.2125712

Yang, Jian. Jin Zhang. David J. Leatham. (2003). Price and Volatility Transmission in International Wheat Futures Markets. Analysis Of Economics And Finance 4, 37-50 (2003). Available at: http://down.aefweb.net/AefArticles/aef040103.pdf

\section{Copyright Disclaimer}

Copyright for this article is retained by the author(s), with first publication rights granted to the journal.

This is an open-access article distributed under the terms and conditions of the Creative Commons Attribution license (http://creativecommons.org/licenses/by/3.0/). 